\title{
Budding Method Affects Transmission of Xylella fastidiosa in Plum
}

\author{
G.E. Boyhan ${ }^{1}$, B.R. Abrahams ${ }^{2}$, and J.D. Norton ${ }^{3}$ \\ Department of Horticulture, 101 Funchess Hall, Auburn University, AL 36849 \\ Hongwen Huang ${ }^{4}$ \\ Wuhan Institute of Botany, Chinese Academy of Sciences, Wuhan, Hubei, \\ People's Republic of China
}

Additional index words. phony peach, Prunus spp., Prunus persica, Prunus salicinia, plum leaf scald

\begin{abstract}
Detection of Xylella fastidiosa Wells et al. by enzyme-linked immunosorbent assay indicated that plums (Prunus hybrids) had higher absorbance values than peaches [Prunus persica (L.) Batsch]. The slip-budded trees had lower readings than those that were chip budded; however, the scion $\times$ method interaction was significant. Further comparison of slip vs. chip budding indicated that the lower absorbance value of slip budding occurred in plums only; there was no difference between budding methods in peach.
\end{abstract}

Plums and peaches are important tree crops in the southeastern United States, but they are affected by Xylella fastidiosa Wells et al., the bacterium causing plum leaf scald (PLS) and phony peach disease (Wells et al., 1987). Xylella fastidiosa is a xylem-limiting bacterium that affects various plant species (Sherman, 1989).

This bacterium infects only the xylem tissue of the host, causing marginal necrosis in leaves of plum that can result in the stunting and death of plant branches. In peaches, the pathogen causes significant reductions in fruit size, shoot length, and yield. Loss in fruit size is so serious that crops become nonmarketable.

Peaches and plums are propagated asexually by budding onto suitable rootstocks to ensure true-to-type cultivars for production. This method of propagation, however, spreads the pathogen from diseased rootstocks to pathogen-free scions (Latham et al., 1980).

This study was undertaken to evaluate the effect of budding method (with or without xylem tissue), scion source (peach and plum), and rootstock source (Nemaguard and Lovell) on the transmission of $X$. fastidiosa as measured by enzyme-linked immunosorbent assay (ELISA) absorbance values.

\section{Materials and Methods}

Seed obtained from indexed virus-free trees of Lovell and Nemaguard (Haley Nursery, McMinnville, Tenn.) were stratified in the

Received for publication 15 May 1995. Accepted for publication 28 Oct. 1995. Alabama Agricultural Expt. Station journal no. 11-955013. The cost of publishing this paper was defrayed in part by the payment of page charges. Under postal regulations, this paper therefore must be hereby marked advertisement solely to indicate this fact.

${ }^{1}$ Senior Research Associate.

${ }^{2}$ Former Graduate Student.

${ }^{3}$ Professor Emeritus.

${ }^{4}$ Associate Professor. endocarp at $5 \mathrm{C}$ for 4 months in moist sand. The endocarp was removed in Jan. 1993 and the seed were planted in $28 \times 53-\mathrm{cm}$ flats of Metromix 300 (Cambridge, Mass.) in a greenhouse at 20 to $35 \mathrm{C}$.

Seedlings that were 10 to $20 \mathrm{~cm}$ tall were transplanted into 3.8-liter containers of a 7 pine bark : 1 sand medium [with $1.7 \mathrm{~kg}$ lime, $0.5 \mathrm{~kg}$ Micromax (Scotts, Marysville, Ohio), $5.4 \mathrm{~kg}$ Osmocote 14-14-14 (Scotts) $\left./ \mathrm{m}^{3}\right]$. These transplanted trees then were moved to an insect-free screenhouse. ELISA for $X$. fastidiosa antigens was performed on a random sample of these trees to verify that they were free of the pathogen.

In late Spring/early Summer 1993, these trees were double-budded (two buds per tree) with buds from trees that showed symptoms and tested positive for $X$. fastidiosa. Slip buds were made using a conventional T-bud where care was taken to remove any xylem tissue attached to the bud. We used the same method for chip budding, except that no xylem tissue was removed from the bud. Instruments used in budding were cleaned in $70 \%$ ethanol solution after each tree was budded. After placement of the bud, each was wrapped with $1-\mathrm{cm}$-wide polyethylene tape to hold it in place. The tape was removed as soon as leaves were visible.

The experiment was arranged as an augmented factorial of $2 \times 2 \times 2$ with two budding methods (slip and chip budding), two rootstocks (Lovell and Nemaguard), and two infected scions ('AU-Rubrum' plum and 'Loring' peach). The design was a randomized complete block with four replications of five trees per treatment within a replication. Augmenting the factorial were two additional treatments: a nonbudded Lovell and nonbudded Nemaguard as controls, for a total of 10 treatments of 20 trees each (five trees $\times$ four replications). In Fall 1993, two samples of $0.1 \mathrm{~g}$ of leaves and petioles from scions derived from infected buds were removed from each tree and were evaluated with ELISA (Agdia, Elkhart, Ind.) according to the ELISA kit manufacturer's directions. Absorbance values (wavelength of $490 \mathrm{~nm}$ ) for ELISA were read with a MR 700 microplate reader (Dynatech Labs, Chantilly, Va.) $\approx 1 \mathrm{~h}$ after adding substrate.

\section{Results and Discussion}

Scions were considered positive for PLS with the ELISA test when the standard deviation was two units larger than for the nonbudded controls. Using this criterion, the nonbudded plants had a mean absorbance value of 0.015 and a standard deviation of 0.005 ; therefore, scions with absorbance values $>0.025$ were considered infected. 'Loring' peach scions had no infected scions, while 'AU-Rubrum' plum scions had $>60 \%$ infected (Table 1 ). The plum scions had a mean absorbance value more than eight times higher than the peach scions. There was no difference in scions between Lovell and Nemaguard rootstocks. The mean absorbance value was significantly higher with chip budding than with slip budding, with a percent positive reaction more than double. Additionally, the chip-budded

Table 1. Means and analysis of variance significances for enzyme-linked immunosorbent assay for Xylella fastidiosa antigen in leaf and petiole tissue of plum and peach by rootstock, scion, and budding method.

\begin{tabular}{|c|c|c|c|}
\hline Factor & $\begin{array}{c}\text { Mean absorbance } \\
(490 \mathrm{~nm})\end{array}$ & $\begin{array}{c}\text { Positive reaction } \\
(\% \text { of total })\end{array}$ & $\begin{array}{c}\text { Significance } \\
(P>\mathrm{F}) \\
\end{array}$ \\
\hline Scions & & & 0.001 \\
\hline AU-Rubrum plum & 0.088 & 63 & \\
\hline Loring peach & 0.010 & 0 & \\
\hline Rootstocks & & & 0.582 \\
\hline Lovell & 0.054 & 38 & \\
\hline Nemaguard & 0.044 & 25 & \\
\hline Budding methods & & & 0.034 \\
\hline Slip & $0.022 \mathrm{a}^{\mathrm{y}}$ & 19 & \\
\hline Chip & $0.076 \mathrm{~b}$ & 44 & \\
\hline Nonbudded & $0.015 \mathrm{a}$ & 0 & \\
\hline \multicolumn{4}{|l|}{ Interactions } \\
\hline Scion $\times$ rootstock & & & 0.551 \\
\hline Scion $\times$ method & & & 0.008 \\
\hline Rootstock $\times$ method & & & 0.829 \\
\hline Scion $\times$ rootstock $\times$ method & & & 0.884 \\
\hline
\end{tabular}

HortScience, Vol. 31(1), February 1996 
Table 2. Enzyme-linked immunosorbent assay for Xylella fastidiosa antigen in leaf and petiole tissue of peach and plum by slip and chip budding methods within 'AU-Rubrum' or 'Loring' scions.

\begin{tabular}{lccc}
\hline \hline Factor & $\begin{array}{c}\text { Mean absorbance } \\
(490 \mathrm{~nm})\end{array}$ & $\begin{array}{c}\text { Positive reaction } \\
(\% \text { of total })\end{array}$ & $\begin{array}{c}\text { Significance } \\
(P>\mathrm{F})\end{array}$ \\
\hline AU-Rubrum & & & 0.001 \\
Slip vs. chip & 0.033 & 38 & \\
Slip budding & 0.143 & 88 & 0.953 \\
Chip budding & & & \\
Loring & 0.011 & 0 & \\
Slip vs. chip & 0.009 & 0 & \\
Slip budding & & & \\
Chip budding & & & \\
\hline
\end{tabular}

${ }^{2}$ Values are means of 40 observations.

trees had a mean absorbance value five times higher than nonbudded trees (Table 1).

Of all the possible interactions, only the scion $\times$ method interaction was significant; therefore, the budding method for each scion was evaluated separately (Table 2 ). For 'AURubrum' plums, the chip-budding method had a mean absorbance value four times greater than slip budding. The values were similar for budding method with 'Loring' peach scions.

This study indicated that using the slipbudding method will greatly reduce the transmission of PLS in plums but not in peach. Early work with peaches indicated no trans- mission of the pathogen by grafting (Hutchins, 1933). Later work by Hutchins et al. (1953) showed that the pathogen could be transmitted by grafting in peach, but the authors concluded that the pathogen was more generally distributed in plum tissue than in peach tissue, resulting in easier transmission in plum. Our study supports these early findings. PLS may be delayed or partially controllable in plum by carefully applying slip budding and sanitary practices. The standard propagation practice in the southeastern United States has been to June (slip) bud on seedling rootstocks; however, little concern is given to the amount of xylem tissue that may remain with the bud. Additionally, PLS is transmitted by leafhoppers [Homalodisca coagulata (Say)] and there are many host plants, feral and cultivated. Therefore, the usefulness of this method under field conditions may be limited.

\section{Literature Cited}

Hutchins, L.M. 1933. Identification and control of the phony disease of the peach. Georgia Offic. State Entomol. Bul. 78.

Hutchins, L.M., L.C. Cochran, W.F. Turner, and J.H. Weinberger. 1953. Transmission of phony disease virus from tops of certain affected peach and plum trees. Phytopathology 43:691696.

Latham, A.J., J.D. Norton, and M.W. Folsom. 1980. Leaf scald on plum shoots growing from disease-free buds. Plant Dis. 64:995-996.

Sherman, W.B., C.E. Yonce, W.R. Okie, and T.G. Beckman. 1989. Paradoxes surrounding our understanding of plum leaf scald. Fruit Var. J. 43:147-151.

Wells, J.M., B.C. Raju, H.Y. Hung, W.G. Weisburg, L. Madelco-Paul, and D.J. Brener. 1987. Xylella fastidiosa gen. nov., sp. nov.: Gram-negative, xylem-limited, fastidious plant bacteria related to Xanthomonas spp. Intl. J. Syst. Bacteriol. 37:136-143. 